\title{
Review of The Yacyreta High Dam: Transnational Capitalism and Hydropolitics in Argentina, by Gustavo Lins Ribeiro 1994, Gainesville: University Press of Florida.
}

\author{
Reviewed by Kendall V. House, Department of Anthropology, Boise \\ State University
}

Rarely do revised dissertations come with accolades equal to the praise with which Eric Wolf anoints this work of his student, Gustavo Lins Ribeiro. The Yacyreta High Dam, according to Wolf, marks "a turning point" in "the growth and maturation of a system of knowledge" (xiii). It represents, in Wolf's opinion, something of an anthropological milestone.

If Ribeiro's work marks a turning point, it is because it helps highlight the analytical limits of Wolf's approach to political economy. And it is here, in transcending the limits of Wolf's political economy without abandoning its very real strengths, that we must look for Ribeiro's contribution in the future.

Given the readership of this journal, it must be acknowledged that The Yacyreta High Dam is not a work of political ecology. By this I mean that very little analysis is presented of the ecological dynamics involved in this massive restructuring of a river, nor does Ribeiro present much in the way of a historical vision of the ecology of the Parana watershed. Anyone hoping for analyses analogous to those of Donald Worster (e.g., Worster 1985) will be disappointed. Of course, it must be recognized that Ribeiro had other aims, and that this research in political economy is still of great interest.

To appraise Ribeiro's work fairly we must begin from his stated aims. As with most dissertation researchers, the sheer scale and scope of Ribeiro's ambitions were somewhat unrealistic, and the resulting insights are sometimes only tenuously coordinated. In getting to the core of the book, a number of these can be set aside. Most notably, this includes his intention to rethink the meaning of development, the final discussion of which (pages 156164 ) is somewhat anticlimactic. Did anyone ever genuinely doubt that "development" was and is about economic expansion, and that the benefits of that expansion are asymmetrically distributed?

More to the point is Ribeiro's focus on the Yacyreta project as a particular form of large-scale production. It has long been part of Wolf's agenda to make large-scale forms of production, like plantations and mines, anthropologically thinkable. It is here that Ribeiro excels. Developing the analytical tools that make large-scale construction projects like the building of high dams intelligible as social entities is no mean feat, and for this alone Ribeiro deserves our respect.

The structure of the book largely follows from this focus, and it is in this context that the reason for Wolf's enthusiasm for Ribeiro's work becomes clear. The analysis itself begins with Chapter Two, which briefly characterizes the dam's structural features and then offers a detailed analysis of the "institutional triangle" of owner, consultant, and main contractor that organizes a long term, multi-decade, multi-billion dollar project like Yacyreta. This is followed by a careful, historical analysis that situates the emergence of this complex institutional framework in the context of the tumultuous domestic and 
international political climate characterizing Argentina and Paraguay from the 1960s to the 1980s.

Chapter Three, aptly titled "The Power of a Dam," amplifies this historical analysis by situating it internationally. As Ribeiro argues, "A huge dam is a world market happening that articulates national and international industrial capital with the mediation of national states" (51). To his credit, his analysis avoids vague world systems concepts like core and periphery, and focuses on a detailed analysis of the interpenetration of international financial institutions, multinational contractors, and the changing cast of national political interests in Argentina and Paraguay. Beyond an adroit rendering of a remarkably complex social reality, Ribeiro's signal contribution here is advancing the concept of consortiation as a way of marking "this process through which a large-scale project promotes the articulation of different capitals" as a central analytical focus (81). The main vehicle for analyzing consortiation is a laborious analysis of the politics involved in the bidding of two of the main components in the dam's construction, the main civil works and turbine contracts.

Chapter Four, "The Moon Land", makes a smooth transition from the analysis of capitalist and state institutions to an analysis of the Yacyreta Project as a physical happening in a particular locality. Ribeiro's central goal is to show how "[t]he internal differentiations of large-scale projects are translated into concrete features of the settlement pattern of project territories" (86). It is a goal that he succeeds at masterfully. The bulk of the chapter is concerned with detailing and differentiating the construction of the various housing projects in the Argentinean sector of the project in the vicinity of the town of Ituzaingo. It is here that one of the most notable features of large-scale construction projects - namely their use of an international labor force - is scrutinized, as are the differential conditions for social reproduction allocated to laborers and managers. This is followed by Chapter Five, "Dividing the World", which concludes the analysis by offering an insightful account of labor market segmentation in the project. Here Ribeiro introduces the only recognizably ethnographic segment of the entire book, in a discussion of the "Bicho-de-Obra" or "work-site animal" (see also Ribeiro 1989). Once again, the sociological intelligence at work here is impressive, sorting out the varying migratory rhythms and social situations of workers involved in different aspects of the project.

On either end of these four compact, well-wrought chapters are introductory and concluding chapters that are somewhat disorienting. The introduction tends to wander through topics that distract from his central accomplishment - producing a nuanced, coherent analysis of a large-scale project. The conclusion, on the other hand, both carries forward this initial disorientation with an unspectacular critique of development that seems stapled on, and fails to recognize and recapitulate his primary accomplishment. It is as though, having lifted a mighty stone over his head, Ribeiro feels compelled to wobble around discussing where the shadow might fall. None of this should detract from what he accomplishes in the main body of the analysis, and it is not surprising that his dissertation won an award in Brazil.

It is also not difficult to see why Wolf finds it appealing. The Yacyreta High Dam is first and foremost a solid analysis of the political contests involved in the construction of a massive dam on the Parana River through the joint efforts of Argentina and Paraguay, set against a backdrop of national and international politics, finance, and banking. A great deal of the analysis concerns the competition of national and international interest groups who hope to benefit from building the dam. But more than this, it shows the strength of the Stewardian, rather than Marxist, roots of Wolf's thinking. Steward's focus on levels of 
integration is creatively developed in terms of analyses of the integration of capitals of various origins and scales, on the one hand, and the integration of labor markets of equally various origins and scales, on the other. For anthropologists, perhaps the most intriguing aspect is Ribeiro's transformation of the language of segmented labor markets into the analysis of a situated, spatio-cultural event. The project that Steward initiated with The People of Puerto Rico (Steward et al., 1956) finds a worthy heir here. Equally powerful is Ribeiro's treatment of the large-scale project as a distinct kind of sociological form, an analysis that shows the same sort of sociological imagination evident in Wolf's early work on plantations in the Americas (Wolf 1959). Situated thus, it is easy to follow Ribeiro's work expanding into a comparative study of the large-scale high dam as a social form originating in the American West early in the twentieth century and going world-wide in the decades following World War II. For readers interested in large-scale industrial enterprises as social and cultural forms, such possibilities are tantalizing. Lastly, Ribeiro carries forward and develops Wolf's analysis of segmented labor markets that was briefly initiated in Europe and the People Without History (Wolf 1982).

If Wolf's influence suffuses Ribeiro's work with much of its strength, it also contributes to several weaknesses that prevail, in the end, over Ribeiro's good intentions. For an anthropological readership, perhaps the most notable of these is the startling lack of ethnographic density and cultural analysis that characterizes the study. If Ribeiro was sincere in stating at the outset that he did not want "to reduce my study to an analysis of the cold dynamics of political and economic relations" (xix), he certainly failed. At no point in the study do we truly settle down into the immediate worlds of finite, multidimensional human beings, hear their voices, or see their gestures. The narration is not only omniscient, but distant and thin. Ribeiro's discussion of the Bichos-de-Obra is the closest thing to an exception, but even here the analysis remains aloof and summarizing, and disturbingly acultural. To his credit, Ribeiro seems genuinely concerned to transcend this limitation, which is perhaps the most characteristic and debilitating feature of Wolfian political economy. Nonetheless, his invocation of Geertzian concepts like "local knowledge" are never more than empty gestures.

Closely related to this evacuation of the ethnographic is what we might call a top-down bias. In Ribeiro's hands, the Yacyreta Project is very much the work of financiers, politicians, managers, and engineers. His claim to have conducted "research with the main segments of the population participating in this project, from its transnational elites to local gauchos" (xx) only amplifies the frustration that anyone who has participated in the gritty world of construction must feel with this study. There is no entry provided into the worlds of work of common laborers or equipment operators; beyond a brief overview, we have no entry to their life beyond the job. And aside from a brief discussion of the relative strength of organized labor in Paraguay and Argentina, Ribeiro presents no discussion of those who labor as a segment of the political reality of the project. This last absence points to one of the most curious lacunae in Wolfian political economy, namely, the deletion of close analyses of labor processes and the life-worlds of laborers in favor of the analysis of commodities and markets.

In summary, Wolf is correct to suggest that Ribeiro has accomplished something noteworthy here. But if this work marks a milestone, it is double-edged. Above all else, the considerable strengths of Ribeiro's book make visible the limits of Wolf's variety of political economy, and cannot help but provoke a blend of admiration and dissatisfaction. At the same time, it is quite evident from his stated desire to achieve a rich ethnographic 
analysis of the lives of those involved with the Yacyreta Project that Ribeiro's ambitions transcend those of Wolf. And there lies the promise of the future.

\section{References Cited}

Ribeiro, Gustavo Lins 1989 Ethnic Segmentation of the Labor Market and the >Work Site Animal': Fragmentation and Reconstruction of Identities within the World System. in Jane Schneider \& Rayna Rapp, eds., Articulating Hidden Histories: Exploring the Influence of Eric R. Wolf, p. 336-350. Berkeley: University of California Press.

Steward, Julian, Robert Manners, Eric Wolf, Elena Padilla Seda, Sidney Mintz, and Raymond Scheele

1956 The People of Puerto Rico: a Study in Social Anthropology. Urbana: University of Illinois Press.

Wolf, Eric

1959 Specific aspects of plantation systems in the New World. in Angel Palerm \& Vera Rubin, eds., Plantation Systems in the New World, p. 136-146. Washington, D.C.: Pan American Union.

1982 Europe and the People Without History. Berkeley: University of California Press.

Worster, Donald

1985 Rivers of Empire. New York: Oxford University Press. 